\title{
Claims of employment discrimination and worker voice
}

\author{
Keith A. Bender* \\ John S. Heywood** \\ Michael P. Kidd***
}

\begin{abstract}
Using the U.S. National Study of the Changing Workforce survey, we show that claims of racial and gender discrimination emerge less frequently in workplaces with established worker voice mechanisms. This result accords with the hypothesis that participation enhances perceptions of workplace fairness. We show that while having a supervisor of the same race or gender is associated with reduced discrimination claims, the role of voice tends to be larger when the race or gender of the supervisor is different from that of the worker. This suggests that voice may be particularly important in heterogeneous workplaces.
\end{abstract}

Keywords: worker voice, heterogeneous workplaces, discrimination claims

*(corresponding author) SIRE Professor of Economics, University of Aberdeen, Department of Economics and Centre for European Labour Market Research, University of Aberdeen, Aberdeen AB24 3DH, Scotland, UK; phone: 44(0)1224-273411; email: kabender@abdn.ac.uk

**Distinguished Professor of Economics, University of Wisconsin-Milwaukee, Department of Economics, University of Wisconsin-Milwaukee, PO Box 413, Milwaukee, WI 53201, USA; phone: 1-414-229-4437; email: heywood@uwm.edu

****Professor of Economics, RMIT University, GPO Box 2476, Melbourne VIC 3001 Australia; phone: 61-3-9925-5828; email: michael.kidd@rmit.edu.au 


\section{Claims of Employment Discrimination and Worker Voice}

\section{INTRODUCTION}

Employment discrimination claims represent a substantial cost for many employers. The costs include large legal bills to defend discrimination claims, settlements, damage awards and negative reputational effects. Avoiding such costs explains why firms devote substantial resources trying to forestall discrimination claims. ${ }^{1}$ Human resource management mechanisms that successfully provide two-way communication may limit race and gender discrimination claims with the potential for significant cost savings.

We join a long-standing literature by using direct individual survey data to explore the determinants of discrimination claims (e.g. Kuhn, 1987, 1990; Barbezat and Hughes, 1990; Heywood, 1992; Hampton and Heywood, 1993; Neumark and McLennan, 1995; Hallock, 1998; Antecol and Kuhn, 2001; Shields and Price, 2002; Robst et al. 2003; Banerjee, 2008; Antecol et al. 2009; Adams et al. 2014). Researchers rely on such survey data as the details in court records are not standardized and as the vast majority of employment discrimination cases are either dropped or settled, leaving no record. The self-reported claims of discrimination are seen as a necessary antecedent to seeking remedy and the pattern is viewed as illustrative of the sources of costly litigation.

Our analysis builds on several decades of study of the role that employee voice and managerial responsiveness play in determining firm outcomes and employment relations. The firm outcomes studied are numerous and include improved performance of the firm, better labor relations and, critical for our purpose, a stronger shared sense of fairness. Thus, Bryson (2004) and Bryson et al. (2006) demonstrate that when worker voice is encouraged and managers are responsive, labor productivity is higher. Similarly, Greenberg (2002) shows that voice in the development of an outcome enhances the perceived fairness in the workplace independent of the actual effects of its implementation. An organization that provides

\footnotetext{
${ }^{1}$ We recognize that these costs are not the full social costs of discrimination but only those potentially borne by the employer. Other costs include any uncompensated damage and court costs to victims and the social inefficiency associated with human resources improperly allocated.
} 
knowledge to employees about procedures and listens to employee concerns is more likely to be perceived as fair even holding the outcome constant.

The current paper melds the two issues examining worker voice mechanisms as a potential determinant of claims of discrimination. Previous literature suggests that more developed voice mechanisms may help improve perceptions of fairness. We argue this may lower claims of discrimination. Our empirical analysis provides a nuanced story. We show that the effectiveness of worker voice in mitigating claims of discrimination depends crucially on the differences in the race and gender of the worker and supervisor.

The next section motivates our analysis by discussing the importance of voice, the measurement of discrimination claims and previous research. The third section describes our data and methodology. The fourth section presents our results and a series of robustness checks. The fifth section concludes and suggests avenues for future research.

\section{MOTIVATION AND BACKGROUND}

The idea of voice is closely aligned with the canonical view of unions as detailed by Freeman and Medoff (1986) building on the work of Hirschman (1970). This view claims that unions provide a mechanism through which workers can express discontent and suggest change. Moreover, the independence of unions implies that workers anticipate that managers will "hear" what is said and be responsive with the potential to improve firm performance. Yet, critically, much of this dynamic need not be exclusive to union representation. It might be thought of more broadly as mechanisms of "participation" that could be replicated, or even improved upon, without union representation (Marchington and Wilkinson, 2000). ${ }^{2}$ Indeed, in their study of voice mechanisms and productivity, Bryson et al. (2006) show that the benefits of voice mechanisms are substantially larger in nonunion settings. Thus, managers are encouraged to develop a culture in which workers voice concerns and are willing to take charge in resolving problems (Adler-

\footnotetext{
${ }^{2}$ See Benson and Brown (2010) for a contrasting view that voice is enhanced when there is both union and nonunion forms of voice present.
} 
Milstein et al.2011). This participation can benefit the technical "process" of production as well as generate a shared sense of fairness. This has been the focus of increased research on nonunion forms of voice across a variety of disciplines (Kaufman, 2015).

Social psychologists emphasize that voice enhances the perception of fairness for a given outcome. In their confirmation of this, Lind et al. (1990: 952) state that "it has long been known that the opportunity to present information relevant to a decision enhances judgments of the fairness of the decision-making procedure." They go on to claim the "voice effect is probably the best documented phenomenon in procedural justice research." While not all of this research relates directly to the workplace, it has been replicated in the workplace where perceptions of fairness vary with the extent of voice even with the outcome held constant (Greenberg, 2002). More recently, Charlwood and Pollert (2014) examine employee grievances among a sample of low-wage, non-union workers. They conclude that where management has a policy of meeting regularly to discuss workplace issues, workers report fewer and less serious problems and greater satisfaction with outcomes, all else equal. Indeed, the view that voice influences fairness is evident in those prescribing specific managerial responsibilities associated with ensuring a fair workplace. “These responsibilities include giving adequate consideration to employees' viewpoints, suppressing biases, applying decision-making criteria consistently, providing timely feedback, giving justification and being truthful in communication." (Folger and Bies, 1989) Important for us is that four of these six characteristics are clearly associated with the level and quality of communication between workers and managers, one of the main workplace characteristics that we can measure in our data.

We emphasize that one-way communication from workers is insufficient. It must be, as suggested earlier, communication that workers feel will be discussed, carefully considered and potentially acted upon. Indeed, Turner and O'Sullivan (2013) provide evidence on this from a large non-union US multinational. They show that the majority of workers who voiced complaints or sought remediation for a problem felt the managerial response was unsatisfactory. Moreover, they indicate that voicing complaints in this unresponsive environment is associated with moves toward union support by the workers involved. Again, the critical point remains that workers must feel voice mechanisms in place are responsive. This makes any 
simple listing by management of existing mechanisms of less relevance for our study. Having a suggestion program for workers can only help generate voice and ultimately perceptions of fairness if workers view the mechanism in place as valuable for resolving issues. This is the basis for our analysis which focuses on worker perceptions of such effectiveness.

While this emphasis on worker perceptions is not unique, it can be contrasted with an alternative empirical approach focusing on earnings differentials by gender or race as important determinants of discrimination claims. This focus runs the risk of ignoring most legally constituted discrimination and has, in general, performed poorly in predicting discrimination claims as argued by Gerson (2007: 116). He shows that the vast majority of employment discrimination claims are not about earnings but rather about job assignment, termination, promotion, harassment, climate and employment itself. Indeed, even among earnings claims, intent and incidents of discriminatory treatment are regarded as more persuasive than statistical evidence on wage differentials (Antecol and Kuhn, 2000: 703). To date there is only modest evidence that workers with larger residual earnings differences by race or gender are more likely to report discrimination (Kuhn, 1987, 1990; Barbezat and Hughes, 1990; Heywood, 1992; Banerjee, 2008; Adams et al. 2014). We return to this issue in our empirical robustness section. We include such measures in our estimations and confirm they play little role. Thus, our study shares with Adams et al. (2014), a view that broad measures of managerial behavior and worker voice may be more important in determining claims of discrimination then are earnings differentials.

Finally, we recognize that self-reported claims of race or gender discrimination are unlikely to perfectly align with the economic or legal definition. Yet, this represents a strength rather than a weakness of our investigation. Cases that do not match the economics definition can still result in judgments for plaintiffs. Cases that do not match the legal definition can still result in enormous legal fees. Our objective is not to measure the determinants of a particular definition of discrimination but rather to examine the determinants of those who feel sufficiently aggrieved to claim they are discriminated against. Claims are likely to be costly to the employer regardless of the merits of the case. 
Thus, this paper fills key gaps in the literature. It focuses on self-reported claims of discrimination and highlights the role played by a broad conception of worker voice. It is the first to show the importance of these voice mechanisms and to emphasize their role in reducing discrimination claims when the supervisor is of a different race or gender. When workers perceive successful voice, they are much less likely to claim race discrimination in the face of supervisor of a different race and are much less likely to claim gender discrimination in the face of a supervisor of a different gender. The next section describes the data and empirical methods.

\section{DATA AND METHODOLOGY}

The data for the analysis are taken from the 2002 wave of the National Study of the Changing Workforce (NSCW), a nationally representative survey of employed individuals in the US in 2002. ${ }^{3}$ This survey focuses on quality of work life, although it also contains detailed information on a wide variety of socioeconomic characteristics of workers, workplace characteristics, and importantly for this study, questions about discrimination at work. All information provided on the workplace comes from worker self-reports. Our sample consists of all observations with complete data resulting in a sample size of 2410 workers.

We utilize two questions on discrimination claims from the NSCW. The first asks workers "do you feel in any way discriminated against in your job because of race or national origin" - which, for simplicity, we refer to as 'race discrimination' - and the second asks the same question about discrimination due to gender. In each case the possible answers are simply, "yes" or "no". We interpret the affirmative to reflect workers who claim to be subject to discrimination. We emphasize that these are broad questions that while limited to the job, do not identify the source of discrimination, and so may originate from the employer, coworker or customer. Nor do they identify the type of discrimination: in pay, promotion or job assignment.

\footnotetext{
${ }^{3}$ While somewhat dated, this is one of few surveys that has information on perceptions of discrimination by the worker, aspects of union and nonunion voice and the demographic characteristics of the worker's supervisor. Regardless, the relationship of voice and discrimination described here should be independent of the time period. The dataset is a nationally representative telephone sample of the US working population in 2002 sponsored by the Families and Work Institute, a nonprofit, nonpartisan research think tank. More details can be found at: http://www.familiesandwork.org/national-study-for-the-changing-workforce/.
} 
Despite being broad, they explicitly ask about discrimination on the job and are very similar to the questions used in prior work on determinants of discrimination claims. If voice mechanisms have an influence, it seems likely to do so across the broad set of circumstances these questions identify.

As shown in Table 1, approximately 6.0 percent of the overall sample, claim they are subject to race discrimination, with nonwhite workers much more likely to make the claim (13.8 percent) than white workers (3.6 percent), a statistically significant difference. Males make claims of race discrimination more often (8.2 percent) than females (3.8 percent), a difference that is also statistically significant. The data indicate 8.5 percent of all workers claim gender discrimination with females significantly more likely to make a claim than males (11.6 compared to 5.5 percent). There is no statistical difference in claims of gender discrimination by race. Workers who share the race or gender of their supervisor are less likely to claim race or gender discrimination. Although we cannot test this in our data, one possible explanation might be that white or male supervisors tend to furnish minority or female workers worse performance evaluations, raises, promotion chances and/or job assignments (e.g. Elivra and Town, 2001; Castilla, 2008; Madden, 2012). One of the issues we examine is whether or not these differences isolated in the simple averages in Table 1 persist after controlling for a number of factors.

We explore several proxies for voice, based on the recognition that successful voice requires managers to convey both information about the workplace and their openness to worker suggestions. ${ }^{4}$ The latter is typically associated with a willingness to listen and respond to concerns raised in a fair and supportive manner (Detert and Burris, 2007). The response by workers, in turn, should increase information provided to managers about the workplace (Detert and Trevino, 2010; Adler-Milstein et al. 2011). The ability to give voice to workplace issues has been identified with increased willingness to act to address issues because of the resulting increased sense of empowerment or autonomy (Adler-Milstein et al. 2011).

\footnotetext{
${ }^{4}$ The very broad literature across academic disciplines leads to a number of ways of conceptualizing the dimensions of voice (see Dundon et al. 2004 and Kaufman 2015 for discussions of this), but the three measures available to us in the data are broadly aligned with previous research. Just to name a couple of examples: Kaufman (2015, p. 23) highlights the importance of communication, while Budd (2011, p. 67) and Lawler (1986, p. 3) suggest an important role for autonomy and information flows in voice, respectively.
} 
Using this framework we identify the flow of information from workers to supervisors by utilizing a question that asks whether "My managers seek information/new ideas from employees". Table 1, column 3 documents that almost $73 \%$ either agree or strongly agree with the above statement. There are only small differences by race and gender and only the latter shows any statistical difference. Heterogeneity in supervisor race or sex also makes little difference in the provision of this kind of voice.

The second measure of voice builds up from a series of four questions relating to communication and support provided by the supervisor. The first component relates to the information flow from the supervisor, "My supervisor keeps me informed of things I need to do the job well". The second and third components relate to the expectations and communication about success: "My supervisor has realistic expectations of my job performance" and "My supervisor recognizes when I do a good job". The final component focuses on the expectations of the worker about management's response to work problems, "My supervisor is supportive when I have a work problem". These variables are all coded using a 5-point Likert scale, and we use the first principle component of these responses to generate a binary variable (when the principle component exceeds zero) that indicates a high level of voice ("Communication and Support"). Table 1 indicates that approximately 63 percent experience high levels of supervisor communication and support, with only modest differences across demographic characteristics.

The final measure we examine is autonomy, or the ability to make one's own decisions about work. Much of the rationale for managerial initiated voice is to empower workers to solve their own problems. Thus, voice should be associated with greater worker autonomy. Here the specific question states, "I have the freedom to decide what I do on the job". Approximately 64 percent report that they agree or strongly agree with the above statement. Yet for nonwhite (female) workers the equivalent fell to 55.2 (60.4) percent with statistically significant differences between genders and races. Finally, a difference in supervisor and worker race is associated with lower autonomy.

Given the cross-disciplinary nature of research on voice (Kaufman, 2015), no single indicator can hope to capture all of the distinct dimensions. Nonetheless, by trying to control for all the above influences and by examining multiple measures, we hope to uncover the circumstances in which employees claim 
discrimination and broadly identify the role of voice. ${ }^{5}$ We note that voice may influence claims of discrimination in a variety of ways which, unfortunately, we cannot distinguish between. It may influence actual discrimination and be reflected in the reported claims of discrimination. Alternatively, voice may influence discrimination claims in the presence/absence of actual discrimination. All of these influences will be reflected in the probability of making a discrimination claim which is the focus of our analysis.

Whether or not a discrimination claim is made is thus a binary variable, and we estimate all specifications via probit. ${ }^{6}$ For ease of interpretation we convert the key probit coefficients into marginal effects (keeping all other covariates at their sample mean levels). When examining our critical binary indicators of voice, the marginal effects identify the influence of each indicator on the probability that workers make a discrimination claim. All specifications contain controls for gender, race (nonwhite defined as black, Asian, Latino/a or other ethnicity), whether the supervisor and worker are of the same race (in the race discrimination regressions) or whether the supervisor and worker are of the same gender (in the gender discrimination regressions), union status, seven dummies for education, age, age squared, four dummies for region, eight dummies for occupation and four dummies for length of tenure at a firm. The descriptive statistics for these covariates are presented in the Appendix Table 1 with a full set of descriptive statistics available from the authors.

\footnotetext{
${ }^{5}$ Given that workers identify both the voice mechanisms and the discrimination claims there may be 'common rater bias.' This bias emerges when the answers to one question, depend upon the perceptions of another. While not denying this potential, recent research by Conway and Lance (2010) suggests that such bias often does not exist in practice and may even be helpful. Thus, one might argue that the identification of worker voice should come from workers rather than, say, managers. Viewed this way, it is not the policies themselves that affect the claims of discrimination, but rather the perceptions of the success of voice policies that influence claims.

${ }^{6}$ We note that comparable logit estimates reveal essentially similar results for the key measures of voice and little is lost focusing on only the probit estimates.
} 


\section{RESULTS}

Next we turn to a series of regressions designed to estimate the partial correlations between each voice measure and discrimination claims. We follow this with a series of robustness checks. We initially present the basic results on race discrimination claims followed by sex discrimination claims.

\subsection{Race Discrimination Claims}

The top panel of Table 2 summarizes the basic econometric specification where almost all of the correlations (reported as marginal changes in the probability of a discrimination claim) are statistically significant. The means from Table 1 suggest that nonwhites are well over ten percentage points more likely to claim racial discrimination. After including the covariates, this falls to less than five percentage points. Workers are around five percentage points less likely to claim racial discrimination when their supervisor is of the same race. Critically, the role of the voice measures appears substantial when compared to these basic determinants. Workers with supervisors who ask for ideas (“Seeking Information" column) are nearly six percentage points less likely to claim racial discrimination. This is replicated for those workers who experience supportive communication ("Communication and Support" column) from their supervisor. The correlation of autonomy and discrimination claims is in the same direction but appears smaller. Thus, at a first cut, the variety of voice mechanisms appear to be clearly associated with a lower incidence of race discrimination claims.

The impact of unionization on perceived discrimination is also reported in Table 2. A wellestablished literature, championed by Freeman and Medoff (1982) and many others, argues that unions represent another form of voice. In this particular context, Heywood (1992) finds that union members are more likely to claim discrimination regardless of their race and suggested that such complaints may be a form of union voice. Yet, the estimates in Table 2 provide only weak evidence and those in Table 4 (for sex discrimination) provide virtually no statistically significant influences of unionization on claims of discrimination. The most critical point from our perspective is that the voice mechanisms we identify persist in importance after controlling for unionization and, indeed, appear equally effective in either 
setting. ${ }^{7}$ The apparent lack of importance for unions may reflect that differences in the nature of voice between unionized and nonunionized employers is narrowing. Alternatively, unions may play some role in the creation of the mechanisms of voice but not in their success. While tangential to this paper, these remain interesting topics for future work.

Table 1 documents the underlying probability of claiming discrimination is much higher when the worker/supervisor race differ (13.4 compared to 3.7 percent). Given this large influence of the supervisor's race on the likelihood of a worker claiming discrimination, we explore whether the supervisor's race also influences the correlation of the voice mechanisms in reducing those claims. We split the sample into workers with a supervisor of the same/different race. The lower panels of Table 2 document results for each sub-sample. The voice measures continue to suggest lower claims of discrimination in both subsamples, although the point estimates differ substantially. Thus, the 'Seeking Information' voice measure is associated with a $2.7(16.4)$ percentage point smaller probability of a discrimination claim when the supervisor is of the same (different) race. The other voice measures show similar patterns.

We now examine the influence of the voice measures in more detail by identifying dummies for three separate groups of workers. We keep nonwhite workers without voice as a base and then create dummy indicators for white workers with no voice, white workers with voice and nonwhite workers with voice. These estimates are shown in Table 3 and provide measures of the influence of voice that differ by race. The estimates indicate that compared to the base (nonwhite workers with no voice) white workers without voice have a lower probability of making a discrimination claim. However, comparing white workers with and without voice, we see in the fourth row, first column of the top panel, that white workers with managers seeking information are more than six percentage points less likely to claim discrimination than similar white workers without this form of voice. For nonwhite workers, voice is associated with lower claims by nearly four percentage points. Similar results are found for the other two measures of voice

\footnotetext{
${ }^{7}$ In a robustness check suggested by a referee, we interact union status with our voice measures. In seventeen of eighteen specifications there was not a statistically significant interaction. These results are available from the authors upon request.
} 
- communication and support and autonomy - with the decrease being larger for white workers compared to nonwhite workers.

The bottom two panels again split the sample by the supervisor's race. When the supervisor and worker are of the same race, the negative correlations with the voice mechanisms remain for white workers with reductions of 6.6, 3.5 and 4.1 percentage points, respectively for the three voice measures. Yet, when the supervisor and worker are both nonwhite, no statistically significant difference (at 5 percent) can be identified for workers with and without voice. Thus, the earlier suggestion that voice is associated with reduced discrimination claims even when the supervisor and worker are of the same race, is generated largely by white workers. This can be contrasted with the case when the supervisor and worker are of different races. Here, the voice mechanisms are associated with a slightly larger reduction in claims among nonwhite workers. This may seem a particularly relevant case, nonwhite workers with a white supervisor, and it is here that we find the largest association with voice. This hints that voice measures may be particularly effective in reducing claims of discrimination in racially heterogeneous workplaces.

Before examining sex discrimination claims and further robustness checks, it is worth remembering that the nonwhite group is an amalgam of black, Hispanic, Asian and other workers. While some racial categories are relatively small in size, we have repeated the estimations retaining only blacks and whites and the relationship between voice and discrimination claims persists in this tighter comparison and exists for both white and black workers. Moreover, the results continue to suggest that the association is, if anything, stronger for whites. Indeed, if we separately run the regressions by white and non-white samples to allow for the most general specification which allows all coefficients to vary by race, we find that the coefficients on the three voice measures are $-0.034,-0.028,-0.017$ for white workers and $-0.134,-0.172,-$ 0.008 for nonwhite workers, with all being statistically significant at the five percent level, except for the final coefficient estimate. 


\subsection{Sex Discrimination Claims}

We now turn our focus to claims of gender discrimination and summarize the basic specification in the top panel of Table 4, again showing statistical significance for each variable at the one percent level. After controlling for covariates, the results return marginal effects that imply differences roughly half those from the means found in Table 1. Women are more likely (between 3.9 and 4.9 percentage points) to claim gender discrimination. The coefficients on the voice measures are large (between 4.5 and 8.3 percentage points) and indicate that when supervisors seek the ideas of employees, gender discrimination claims are less likely.

As with the race discrimination results, sharing the same gender with the supervisor significantly affects the results. In the top panel, workers of the same gender as their supervisor are over five percentage points less likely to claim discrimination, all else equal. Not only does this largely mimic the results for the race of the supervisor but a similar pattern emerges when examining the connection between the voice mechanisms and the gender of the supervisor. In the bottom two panels of the table, the estimates are run separately on the sample of workers who share/do not share the same gender as their supervisor. The results indicate that voice is associated with a larger reduction in discrimination claims when the supervisor and worker are of different genders (e.g. a 14.2 percentage point reduction compared to a 5.6 percentage point reduction for the 'Seeking Information' measure of voice), again suggesting the importance of voice in a heterogeneous workplace.

As above with race, we next estimate sex discrimination claims including interactions of sex and the voice measures, see Table 5. Once again the results are nearly all statistically significant at the one percent level. For the overall sample (top panel), males, ceteris paribus, are less likely to claim sex discrimination, with voice associated with 6.6 and 4.0 percentage point lower probability of a claim depending on the voice measure (see the 'Test' row). Interestingly, this is about the same level of magnitude as voice for females, which ranges from -6.0 to -3.6 percentage points. These results are, in contrast, to the role of voice among nonwhite workers discussed above, where voice had a much smaller correlation with discrimination claims among nonwhite workers compared to white workers. 
To check for robustness we estimate the regressions separately by gender (results available from the authors), the marginal correlations for females on the three voice measures are $-0.095,-0.105$ and -0.043 while they are $-0.049,-0.049$ and -0.033 for the male sample, where all are statistically significant at the five percent level.

We now split the sample by the sex of the supervisor compared to that of the worker in the bottom panels of Table 5. As shown, when the supervisor shares the same sex as the worker, voice emerges with a small and not always significant correlation in reducing discrimination claims for women and continues to have a modest correlation for males. On the other hand, when the sex of the supervisor differs from that of the worker, voice plays a far larger and statistically significant role. Thus, the first voice measure 'Seeking Information', for example, is associated with a 14.9 percentage point reduction in the likelihood of a gender discrimination claim by a women and a 14.4 percentage point reduction for men, all else equal. Again, this may be a particularly relevant subsample, female workers with a male supervisor and vice versa for males, and it is here that the correlation between voice and discrimination is largest.

Thus the results suggest an important role for voice in mitigating claims of both race and sex discrimination. This is regardless of whether the claims are of race or gender discrimination. The correlations are more negative among workers who differ by gender/race from their supervisors suggesting the importance for voice in demographically heterogeneous workplaces. In the next section, we investigate other possible explanations for the results presented to date.

\subsection{Robustness Checks}

Several additional sets of regressions examine the robustness of the results. First, while the voice mechanisms in the previous regressions were entered individually, it may be the case that interrelationships between the three measures may complement each other. Thus, rather than enter the voice measures individually as in Tables 2 and 4, we include a series of mutually exclusive dummy variables interacting the three voice proxies that capture different combinations of the voice measures, compared to workers with no voice. Results of this exercise are in Table 6. It is clear from the top part of the table, that having 
only one voice measure has a limited effect on mitigating discrimination claims, while having measures seeking information and communication or all three measures result in large negative correlations with discrimination claims. As above, when the supervisor is of a different race or sex (for race or sex discrimination, respectively), the voice measures have a much larger negative correlation, while there is relatively small effects when the supervisor's race or sex is the same as the worker's.

Next, we examine the possibility of the general level of worker wellbeing acting as a confounding effect. Thus, unhappy workers may both complain about managers and claim discrimination. We follow the previous literature and include a measure of subjective well-being as a covariate (Johnson and Neumark, 1997). Tables 7 and 8 report the race/sex-voice interacted models discussed previously including a measure of life satisfaction (a dummy variable indicating whether the worker reports to be satisfied with his/her life). In the overall sample, the correlation between life satisfaction and claims of discrimination work as anticipated with those being satisfied having a lower probability of claiming either race (Table 7) or sex (Table 8) discrimination. We recognize that it is possible that perceptions of discrimination at work may generate low life satisfaction so we are wary of the direction of causation.

The crucial point is that the general tenor of our results discussed above remain. Despite controlling for subjective well-being, the voice measures are associated with a lower probability of claiming discrimination. This association remains strongest among workers who have different sex and race than their supervisors for both types of discrimination. The association between voice and discrimination claims does not seem to be generated simply by those workers unsatisfied with life.

A second potential issue, discussed earlier, is the potential link between typical residual wage measures of discrimination adopted by economists and the potential influence on claims of discrimination. These differentials have been shown to predict earnings adequacy or satisfaction with earnings (Hampton and Heywood, 1993) but typically not discrimination claims. To check for robustness here we estimate log hourly wage equations separately for white and nonwhite workers (in the case of race discrimination) and 
for male and female workers (in the case of sex discrimination). ${ }^{8}$ From those estimates we generate a wage differential that is the predicted white-nonwhite wage for nonwhite workers and the predicted nonwhitewhite wage for white workers and add this differential as an additional regressor in the racial discrimination claim specification. Likewise, for the sex discrimination equation, we include a wage differential variable that is constructed as the predicted male-female wage for females and the predicted female-male wage for males. The differential generated in this way should imply that those with a smaller or more negative differential should be more likely to claim discrimination. Thus, we are testing the role of earnings differences as a determinant of claims but also viewing it as a potential omitted variable that might bias our estimates of the relationship between voice and claims.

Tables 9 and 10 record the results from this robustness test. In keeping with the bulk of the literature, there seems to be no statistically significant relationship between the predicted wage differential and claims of either race or sex discrimination. This is consistent with Gersen (2007) and others who suggest that wage differentials as measured by economists are not a good predictor of discrimination claims and far from the first thing that workers think of when identifying fair treatment. Given that our results also fail to find a role for wage differentials, it is perhaps not surprising that the voice-race/sex results remain, again, qualitatively similar. ${ }^{9}$ For nearly all cases, voice has a statistically significant, mitigating effect on claims of discrimination, particularly when the supervisor and worker are of different sex or race.

Finally, unions are often thought of being unique in their ability to provide voice to workers. While the evidence on this is mixed, as we discussed in the introduction, it is worth noting that we found no statistical differences in the role our key measures of voice played in the union and nonunion sectors. While

\footnotetext{
${ }^{8}$ The wage regression results are available from the authors, but they include standard regressors such as gender, race, supervisor sex and race, union status, education, age, age squared, years in the labor force, firm size, an hourly pay indicator, marital status, region and occupational controls. These are available upon request.

${ }^{9}$ Indeed, we attempted to generate critical levels of the differential that might indicate discrimination such as those more than one standard deviation above the mean. Even such indicators played no role in claims of discrimination and left the voice associations in place.
} 
some of the demographic and other determinants differ, worker perceptions of voice are related to similar reduced claims of discrimination for unionized and nonunionized workers. ${ }^{10}$

\section{CONCLUSION}

The fundamental suggestion of this paper has been that manager initiated voice may reduce claims of employment discrimination on the basis of race and gender. This follows from previous evidence that voice improves the functioning and productivity of the workplace and as suggested by social psychologists that voice changes perceptions of the workplace. When workers feel their comments and suggestions will be met with a careful and reasoned response and the opportunity for continued dialogue, they see the workplace as exhibiting greater fairness. We examine whether, as a consequence, workers are less likely to claim employment discrimination.

The evidence we present shows a robust and durable statistical relationship between several measures of voice and lower claims of both race and sex discrimination. While these relationships persist in most subsamples, the strongest associations of voice and claims become evident when there are differences in race or sex between the worker and the supervisor. Thus, one of the major contributions of our inquiry is a more nuanced role of voice - that voice is particularly associated with lower claims of discrimination in situations where differences in race or sex occur. We confirm that discrimination claims are less likely when the worker has a supervisor of the same race and sex.

Critically, the relationship we identify does not flow simply from a minority of dissatisfied respondents claiming discrimination and that they do not have voice. The relationships persist when controlling for subjective well-being. Moreover, the relationships appear far more important than the economist's measure of earnings differentials. The racial and sex earnings differentials have little or no explanatory power confirming results from the prior literature. Controlling for subjective well-being and the size of the relevant wage differential do not eliminate the relationship between voice and claims of

\footnotetext{
10 These results are available from the authors and fit with our earlier evidence that once the voice mechanisms are
} included there exists no independent role for unionization to play in influencing discrimination claims. 
discrimination. The reduction in claims of discrimination could result from a reduction in the extent of discrimination. This would obviously support the broad policy objective of equal opportunity. It could also result from a reduction in the probability of claiming discrimination even if it exists. This could work against those objectives. Finally, it might result from a reduction in the probability of spurious claims of discrimination. Such a reduction could improve the efficiency of equal opportunities enforcement. All of these sources can be anticipated to reduce the associated legal costs of the firm.

Future work may look for more detail on the specific mechanisms and characteristics of voice that appear successful. More detail on everything from open door policies and suggestion schemes to autonomous work groups might help identify the specific forms of voice that influence the extent of discrimination claims. Similarly, more detail on the type of discrimination claims could prove valuable. Does voice tend to be associated with reduced claims of discrimination in job assignment, promotion, termination or pay? Further work investigating union voice and discrimination would also be an interesting further area of analysis as would a more complete model which could identify causal relationships. Finally, linked worker and employer data could prove important to control for firm characteristics not in typical survey data of workers and which would be from sources other than the workers.

Despite these potential avenues for improvement and more detail, this study suggests that the link between voice, participation and discrimination claims is, indeed, worthy of further study. The costs of discrimination claims are enormous and the evidence that they are less frequent when mechanisms of voice are present argues that such mechanisms may both improve the work life of workers and pay for themselves in reduced litigation expenses. 


\section{REFERENCES}

Adams, S., J. Heywood, and L. Miller. (2014), 'Caregivers, Firm Policies and Gender Discrimination Claims', Review of Economics of the Household, 12, 2, 539-577.

Antecol, H., V. Barcus, and D. Cobb-Clark. (2009), 'Gender-biased Behavior at Work: What Can Surveys Tell Us About the Link between Sexual Harassment and Gender Discrimination?', Journal of Economic Psychology, 30, 5, 782-792.

Antecol, H. and P. Kuhn. (2000), 'Gender as an Impediment to Labor Market Success: Why Do Young Women Report Greater Harm?’, Journal of Labor Economics, 18, 4, 702-729.

Artz, B. (2010), 'The Impact of Union Experience on Job Satisfaction', Industrial Relations, 49, 3, 287305.

Banerjee, R. (2008), 'An Examination of Factors Affecting Perception of Workplace Discrimination', Journal of Labor Research, 29, 4, 380-401.

Barbezat, D. and J. Hughes. (1990), 'Sex Discrimination in Labor Markets: The Role of Statistical Evidence: Comment', American Economic Review, 80, 1, 277-286.

Bender, K. and P. Sloane. (1998), 'Job Satisfaction, Trade Unions and Exit-Voice Revisited', Industrial and Labor Relations Review, 51, 2, 222-240.

Benson, J. and M. Brown. (2010), 'Employee Voice: Does Union Membership Matter?', Human Resource Management Journal, 20, 1, 80-99.

Bryson, A. (2004), 'Managerial Responsiveness to Union and Non-union Worker Voice in Britain', Industrial Relations, 43, 1, 213-241.

Bryson, A., A. Charlwood, and J. Forth. (2006), 'Worker Voice, Managerial Response and Labor Productivity: An Empirical Investigation', Industrial Relations Journal, 37, 5, 438-455.

Budd, J. (2011), The Thought of Work (Ithaca, NY: Cornell University Press).

Castilla, E. (2008), 'Gender, Race, and Meritocracy in Organizational Careers', American Journal of Sociology, 113, 6, 1479-1526.

Charlwood, A. and A. Pollert. (2014), 'Informal Employment Dispute Resolution among Low-Wage Nonunion Workers: Does Managerially Initiated Workplace Voice Enhance Equity and Efficiency?' British Journal of Industrial Relations, 52, 2, 359-386.

Conway, J. and C. Lance. (2010), 'What Reviewers Should Expect from Authors Regarding Common Method Bias in Organizational Research', Journal of Business and Psychology, 25, 325-334.

Detert, J. and E. Burris. (2007), 'Leadership Behavior and Employee Voice: Is the Door Really Open?' Academy of Management Journal, 50, 4, 869-884.

Detert, J. and L. Trevino. (2010), 'Speaking Up to Higher-ups: How Supervisors and Skip-Level Leaders Influence Employee Voice’, Organization Science, 21, 1, 249-270. 
Dundon, T., A. Wilkinson, M. Marchington and P. Ackers. (2004), 'The Meanings and Purpose of Employee Voice', The International Journal of Human Resource Management, 15, 6, 1148-70.

Elvira, M. and R. Town. (2001), 'The Effects of Race and Worker Productivity on Performance Evaluations', Industrial Relations, 40, 4, 571-590.

Folger, R. and R. Bies. (1989), 'Managerial Responsibilities and Procedural Justice', Employee Responsibilities and Rights Journal, 2, 2, 79-90.

Gersen, J. (2007), 'Markets and Discrimination'. New York University Law Review, 82, 3, 101-148.

Greenberg, J. (2002), The Quest for Justice on the Job: Essays and Experiments (Thousand Oaks, CA: Sage Publications).

Freeman, R. and J. Medoff. (1985), What Do Unions Do? (New York: Basic Books).

Hallock, K., W. Hendricks, and E. Broadbet. (1998), 'Discrimination by Gender and Disability Status: Do Worker Perceptions Match Statistical Evidence', Southern Economic Journal, 65, 2, 245-263.

Hampton, M. and J. Heywood. (1993), 'Do Workers Accurately Perceive Gender Wage Discrimination?', Industrial and Labor Relations Review, 47, 1, 36-49.

Heywood, J. (1992), 'Race Discrimination and Union Voice', Industrial Relations, 31, 3, 500-508.

Hirschman, A. (1970), Exit, Voice, and Loyalty: Responses to Decline in Firms, Organizations, and States (Cambridge, MA: Harvard University Press).

Johnson, R. and D. Neumark. (1997), 'Age Discrimination, Job Separations, and Employment Status of Older Workers: Evidence from Self-Reports’, Journal of Human Resources, 32, 4, 779-811.

Kaufman, B. (2015), 'Theorising Determinants of Employee Voice: An Integrative Model across Disciplines and Levels of Analysis', Human Resource Management Journal, 25, 1, 19-40.

Kuhn, P. (1987), 'Sex Discrimination in Labor Markets: The Role of Statistical Evidence',. American Economic Review, 77, 4, 567-583.

Kuhn, P. (1990), 'Sex Discrimination in Labor Markets: The Role of Statistical Evidence: Reply'. American Economic Review, 80, 1, 290-297.

Lawler, E. (1986). High-Involvement Management (San Francisco: Jossey-Bass).

Madden, J. (2012), 'Performance-Support Bias and the Gender Pay Gap among Stockbrokers', Gender \& Society, 26, 3, 488-518.

Neumark, D. and M. McLennan. (1995), 'Sex Discrimination and Women's Labor Market Outcomes', Journal of Human Resources, 30, 4, 713-740.

Robst, J., J. VanGilder, and S. Polacheck. (2003), 'Perceptions of Female Faculty Treatment in Higher Education: Which Institutions Treat Women More Fairly?' Economics of Education Review, 22, 1, 5967. 
Shields, M. and S. Price. (2002), 'Racial Harassment, Job Satisfaction and Intentions to Quit: Evidence from the British Nursing Profession', Economica, 69, 274, 295-326.

Turner, T. and M. O'Sullivan. (2013), 'Speaking Up: Employee Voice and Attitudes to Union in a Nonunion US Multinational Firm’, Industrial Relations Journal, 44, 2, 154-170. 
Table 1. The Distribution of Discrimination Claims

\begin{tabular}{|l|c|c|c|c|c|c|}
\hline Sample & $\begin{array}{c}\text { Race } \\
\text { Discrimination }\end{array}$ & $\begin{array}{c}\text { Sex } \\
\text { Discrimination }\end{array}$ & $\begin{array}{c}\text { Seeking } \\
\text { Information }\end{array}$ & $\begin{array}{c}\text { Communication } \\
\text { and Support }\end{array}$ & $\begin{array}{c}\text { Number of } \\
\text { Autonomy }\end{array}$ \\
\hline Full & $6.0 \%$ & $8.5 \%$ & $71.8 \%$ & $63.3 \%$ & $63.8 \%$ & 2410 \\
\hline Female & 3.8 & 11.6 & 74.6 & 65.6 & 60.4 & 1421 \\
\hline Male & $8.2^{\mathrm{a}}$ & $5.5^{\mathrm{a}}$ & $69.2^{\mathrm{a}}$ & $61.1^{\mathrm{a}}$ & $67.1^{\mathrm{a}}$ & 989 \\
\hline Nonwhite & 13.8 & 8.6 & 72.3 & 63.0 & 55.2 & 510 \\
\hline White & $3.6^{\mathrm{b}}$ & 8.5 & 71.7 & 63.4 & $66.5^{\mathrm{b}}$ & 1900 \\
\hline Superv. same race & 3.7 & 8.7 & 72.1 & 63.7 & 66.0 & 1853 \\
\hline Superv. different race & $13.4^{\mathrm{c}}$ & 8.0 & 71.1 & 61.8 & $56.9^{\mathrm{c}}$ & 557 \\
\hline Superv. same sex & 6.6 & 6.1 & 72.5 & 62.3 & 62.9 & 1589 \\
\hline Superv. different sex & 4.6 & $13.9^{\mathrm{d}}$ & 70.4 & 65.5 & 65.7 & 821 \\
\hline
\end{tabular}

Notes: Data from the $2002 \mathrm{NSCW}$. All averages are weighted by sample weights. Superscripts indicate statistically significant differences (at the $5 \%$ level) between genders $\left({ }^{\mathrm{a}}\right)$, races $\left({ }^{\mathrm{b}}\right)$, racial differences in supervisor $\left({ }^{\mathrm{c}}\right)$, and sex differences in supervisor $\left({ }^{\mathrm{d}}\right)$. 
Table 2. Selected Results from Race Discrimination Claims and Voice Regressions: Marginal Effects

\begin{tabular}{|c|c|c|c|}
\hline & \multicolumn{3}{|c|}{ Voice Measure } \\
\hline Covariate & $\begin{array}{c}\text { Seeking } \\
\text { Information }\end{array}$ & $\begin{array}{l}\text { Communication } \\
\text { and Support }\end{array}$ & Autonomy \\
\hline \multicolumn{4}{|l|}{ Full Sample } \\
\hline Voice Measure & $\begin{array}{l}-0.057 * * * \\
(-5.26)\end{array}$ & $\begin{array}{l}-0.056 * * * \\
(-5.49)\end{array}$ & $\begin{array}{l}-0.018^{*} \\
(-1.68)\end{array}$ \\
\hline Nonwhite & $\begin{array}{l}0.046^{* * * *} \\
(3.04)\end{array}$ & $\begin{array}{l}0.043 * * * \\
(2.85)\end{array}$ & $\begin{array}{l}0.044 \text { *** } \\
(2.78)\end{array}$ \\
\hline Superv. same race & $\begin{array}{l}-0.049 * * * \\
(-3.32)\end{array}$ & $\begin{array}{l}-0.047 * * * \\
(-3.21)\end{array}$ & $\begin{array}{l}-0.053 * * * \\
(-3.42)\end{array}$ \\
\hline Union & $\begin{array}{r}0.015 \\
(1.45) \\
\end{array}$ & $\begin{array}{l}0.017 * \\
(1.71)\end{array}$ & $\begin{array}{l}0.022^{*} \\
(1.84)\end{array}$ \\
\hline \multicolumn{4}{|c|}{ Superv. same race sample } \\
\hline Voice Measure & $\begin{array}{l}-0.027 * * * \\
(-3.50)\end{array}$ & $\begin{array}{l}-0.017 \text { ** } \\
(-2.33)\end{array}$ & $\begin{array}{r}-0.009 \\
(-1.20) \\
\end{array}$ \\
\hline Nonwhite & $\begin{array}{l}0.055^{* * *} \\
(3.46)\end{array}$ & $\begin{array}{l}0.052 * * * \\
(3.26)\end{array}$ & $\begin{array}{l}0.051^{* * *} \\
(3.09)\end{array}$ \\
\hline Union & $\begin{array}{r}0.009 \\
(1.10)\end{array}$ & $\begin{array}{l}0.012 \\
(1.36)\end{array}$ & $\begin{array}{c}0.012 \\
(1.32)\end{array}$ \\
\hline \multicolumn{4}{|c|}{ Superv. different race sample } \\
\hline Voice Measure & $\begin{array}{l}-0.164 * * * \\
(-4.69)\end{array}$ & $\begin{array}{l}-0.203 * * * \\
(-5.96)\end{array}$ & $\begin{array}{l}-0.062 * * \\
(-1.97)\end{array}$ \\
\hline Nonwhite & $\begin{array}{l}0.057 * * \\
(2.00)\end{array}$ & $\begin{array}{l}0.051^{*} \\
(1.86)\end{array}$ & $\begin{array}{l}0.062^{* *} \\
(2.10)\end{array}$ \\
\hline Union & $\begin{array}{c}0.018 \\
(0.46)\end{array}$ & $\begin{array}{l}0.017 \\
(0.43)\end{array}$ & $\begin{array}{l}0.030 \\
(0.70)\end{array}$ \\
\hline
\end{tabular}

Notes: $* * *$, and $* * *$ indicate statistical significance at the $10 \%, 5 \%$ and $1 \%$. Other controls include gender, supervisor same race as worker (when applicable), union status, education, age, age squared, region, occupation, and tenure at firm. Marginal effects are calculated using the mean values of other variables. Numbers in parentheses are asymptotic z-statistics. All regressions are weighted using sample weights. The sample average of perceived race discrimination is $0.060,0.037$ and 0.134 for the full, same race and different race samples, respectively. 
Table 3. Selected Results from Interactions of Race and Measures of Voice: Marginal Effects

\begin{tabular}{|c|c|c|c|}
\hline 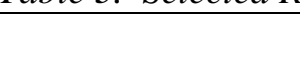 & \multicolumn{3}{|c|}{ Voice Measure } \\
\hline Covariate & $\begin{array}{c}\text { Seeking } \\
\text { Information }\end{array}$ & $\begin{array}{l}\text { Communication } \\
\text { and Support }\end{array}$ & Autonomy \\
\hline \multicolumn{4}{|l|}{ Full Sample } \\
\hline $\begin{array}{l}\text { White novoice } \\
\text { (WN) }\end{array}$ & $\begin{array}{l}-0.032 * * * \\
(-2.66)\end{array}$ & $\begin{array}{l}-0.039 * * * \\
(-3.47)\end{array}$ & $\begin{array}{c}-0.019 \\
(-1.39)\end{array}$ \\
\hline $\begin{array}{l}\text { White voice } \\
\text { (WV) }\end{array}$ & $\begin{array}{l}-0.099 * * * \\
(-5.96)\end{array}$ & $\begin{array}{l}-0.091 * * * \\
(-6.25)\end{array}$ & $\begin{array}{l}-0.051 * * * \\
(-3.39)\end{array}$ \\
\hline Nonwhite voice & $\begin{array}{l}-0.035 * * * \\
(-3.37) \\
\end{array}$ & $\begin{array}{l}-0.040 * * * \\
(-4.06)\end{array}$ & $\begin{array}{c}-0.001 \\
(-0.03) \\
\end{array}$ \\
\hline Test: WV-WN=0 & $\begin{array}{l}-0.067 * * * \\
{[17.47]}\end{array}$ & $\begin{array}{l}-0.052 * * * \\
{[12.47]}\end{array}$ & $\begin{array}{l}-0.032 * * \\
{[6.28]}\end{array}$ \\
\hline \multicolumn{4}{|c|}{ Superv. same race sample } \\
\hline $\begin{array}{l}\text { White novoice } \\
\text { (WN) }\end{array}$ & $\begin{array}{l}-0.025 * * * \\
(-2.60)\end{array}$ & $\begin{array}{l}-0.028 * * * \\
(-2.74)\end{array}$ & $\begin{array}{l}-0.032 * * \\
(-2.56)\end{array}$ \\
\hline $\begin{array}{l}\text { White voice } \\
\text { (WV) }\end{array}$ & $\begin{array}{l}-0.091 * * * \\
(-4.33)\end{array}$ & $\begin{array}{l}-0.063 * * * \\
(-3.93)\end{array}$ & $\begin{array}{l}-0.073 * * * \\
(-4.51)\end{array}$ \\
\hline Nonwhite voice & $\begin{array}{l}-0.016^{*} \\
(-1.74)\end{array}$ & $\begin{array}{l}-0.014 \\
(-1.26)\end{array}$ & $\begin{array}{c}-0.001 \\
(-0.07) \\
\end{array}$ \\
\hline Test: WV-WN=0 & $\begin{array}{l}-0.066^{* *} \\
{[8.99]}\end{array}$ & $\begin{array}{l}-0.035^{*} \\
{[3.79]}\end{array}$ & $\begin{array}{l}-0.041 * * \\
{[4.75]}\end{array}$ \\
\hline \multicolumn{4}{|c|}{ Superv. different race sample } \\
\hline $\begin{array}{l}\text { White novoice } \\
\text { (WN) }\end{array}$ & $\begin{array}{r}-0.035 \\
(-2.03) \\
\end{array}$ & $\begin{array}{r}-0.044 \\
(-1.40) \\
\end{array}$ & $\begin{array}{c}-0.050 \\
(-1.31) \\
\end{array}$ \\
\hline $\begin{array}{l}\text { White voice } \\
\text { (WV) }\end{array}$ & $\begin{array}{l}-0.145 * * * \\
(-4.79)\end{array}$ & $\begin{array}{l}-0.146 * * * \\
(-5.28)\end{array}$ & $\begin{array}{l}-0.102 * * * \\
(-2.80)\end{array}$ \\
\hline Nonwhite voice & $\begin{array}{l}-0.121 * * * \\
(-3.32)\end{array}$ & $\begin{array}{l}-0.153 * * * \\
(-4.84)\end{array}$ & $\begin{array}{c}-0.052 \\
(-1.46) \\
\end{array}$ \\
\hline Test: $\mathrm{WV}-\mathrm{WN}=0$ & $\begin{array}{l}-0.110 * * * \\
{[11.48]}\end{array}$ & $\begin{array}{l}-0.102 * * * \\
{[15.86]}\end{array}$ & $\begin{array}{l}-0.052 \\
{[2.17]}\end{array}$ \\
\hline
\end{tabular}

Notes: $* * *$, and $* * *$ indicate statistical significance at the $10 \%, 5 \%$ and $1 \%$. Other controls as in Table 2. Marginal effects are calculated using the mean values of other variables. Numbers in parentheses are asymptotic z-statistics. All regressions are weighted using sample weights. The comparator group is a nonwhite worker with no voice. The 'Test' rows refer to a Wald chi-squared test $(\mathrm{DF}=1)$ for the equality of the coefficients between white workers with voice (WV) and without voice (WN). Numbers in these rows are the difference in marginal probabilities and numbers in brackets are the chi-squared test statistic. The sample average of perceived race discrimination is $0.060,0.037$ and 0.134 for the full, same race and different race samples, respectively. 
Table 4. Selected Results from Sex Discrimination Claims and Voice Regressions: Marginal Effects

\begin{tabular}{|c|c|c|c|}
\hline & \multicolumn{3}{|c|}{ Voice Measure } \\
\hline Covariate & $\begin{array}{c}\text { Seeking } \\
\text { Information }\end{array}$ & $\begin{array}{l}\text { Communication } \\
\text { and Support }\end{array}$ & Autonomy \\
\hline \multicolumn{4}{|l|}{ Full Sample } \\
\hline Voice Measure & $\begin{array}{l}-0.083 * * * \\
(-6.64)\end{array}$ & $\begin{array}{l}-0.082 * * * \\
(-7.22)\end{array}$ & $\begin{array}{l}-0.045^{* * *} \\
(-3.63)\end{array}$ \\
\hline Female & $\begin{array}{l}0.049 * * * \\
(4.12)\end{array}$ & $\begin{array}{l}0.045^{* * * *} \\
(3.86)\end{array}$ & $\begin{array}{l}0.039 \text { *** } \\
(3.24)\end{array}$ \\
\hline Superv. same sex & $\begin{array}{l}-0.051 * * * \\
(-4.44)\end{array}$ & $\begin{array}{l}-0.054 * * * \\
(-4.76)\end{array}$ & $\begin{array}{l}-0.057 * * * \\
(-4.77)\end{array}$ \\
\hline Union & $\begin{array}{c}0.008 \\
(0.52) \\
\end{array}$ & $\begin{array}{r}0.009 \\
(0.66) \\
\end{array}$ & $\begin{array}{c}0.008 \\
(0.52) \\
\end{array}$ \\
\hline \multicolumn{4}{|c|}{ Superv. same sex sample } \\
\hline Voice Measure & $\begin{array}{l}-0.056 * * * \\
(-4.44)\end{array}$ & $\begin{array}{l}-0.054 * * * \\
(-4.72)\end{array}$ & $\begin{array}{l}-0.032 * * \\
(-2.49)\end{array}$ \\
\hline Female & $\begin{array}{l}0.020^{*} \\
(1.73)\end{array}$ & $\begin{array}{r}0.018 \\
(1.54) \\
\end{array}$ & $\begin{array}{c}0.012 \\
(1.00) \\
\end{array}$ \\
\hline Union & $\begin{array}{c}-0.003 \\
(-0.20)\end{array}$ & $\begin{array}{l}1.3 \mathrm{E}-4 \\
(0.01)\end{array}$ & $\begin{array}{c}-0.003 \\
(-0.22)\end{array}$ \\
\hline \multicolumn{4}{|c|}{ Superv. different sex sample } \\
\hline Voice Measure & $\begin{array}{l}-0.142 * * * \\
(-5.07)\end{array}$ & $\begin{array}{l}-0.152 * * * \\
(-5.90)\end{array}$ & $\begin{array}{l}-0.083 * * * \\
(-3.05)\end{array}$ \\
\hline Female & $\begin{array}{l}0.095^{* * * *} \\
(3.50)\end{array}$ & $\begin{array}{l}0.087 * * * \\
(3.38)\end{array}$ & $\begin{array}{l}0.082 * * * \\
(3.05)\end{array}$ \\
\hline Union & $\begin{array}{c}0.034 \\
(0.97)\end{array}$ & $\begin{array}{c}0.034 \\
(1.03)\end{array}$ & $\begin{array}{c}0.034 \\
(0.97)\end{array}$ \\
\hline
\end{tabular}

Notes: $* * *$, and $* * *$ indicate statistical significance at the $10 \%, 5 \%$ and $1 \%$. Other controls include gender, supervisor same sex (when applicable), union status, race, education, age, age squared, region, occupation, and tenure at firm. Marginal effects are calculated using the mean values of other variables. Numbers in parentheses are asymptotic z-statistics. All regressions are weighted using sample weights. The sample average of perceived sex discrimination is $0.085,0.061$ and 0.139 for the full, supervisor same sex and supervisor different sex samples, respectively. 
Table 5. Interactions of Perceived Sex Discrimination and Measures of Voice: Marginal Effects

\begin{tabular}{|c|c|c|c|}
\hline & \multicolumn{3}{|c|}{ Voice Measure } \\
\hline Covariate & $\begin{array}{c}\text { Seeking } \\
\text { Information }\end{array}$ & $\begin{array}{c}\text { Communication } \\
\text { and Support }\end{array}$ & Autonomy \\
\hline \multicolumn{4}{|l|}{ Full Sample } \\
\hline $\begin{array}{l}\text { Male novoice } \\
(\mathrm{MN})\end{array}$ & $\begin{array}{l}-0.034 * * \\
(-2.38)\end{array}$ & $\begin{array}{l}-0.035 * * * \\
(-2.66)\end{array}$ & $\begin{array}{l}-0.031^{*} \\
(-1.88)\end{array}$ \\
\hline $\begin{array}{l}\text { Male voice } \\
(\mathrm{MV})\end{array}$ & $\begin{array}{l}-0.100 * * * \\
(-7.17)\end{array}$ & $\begin{array}{l}-0.095 * * * \\
(-7.22)\end{array}$ & $\begin{array}{l}-0.071 * * * \\
(-5.13)\end{array}$ \\
\hline Female voice & $\begin{array}{l}-0.058 * * * \\
(-4.88)\end{array}$ & $\begin{array}{l}-0.060 * * * \\
(-5.57)\end{array}$ & $\begin{array}{l}-0.036^{* * * *} \\
(-2.85)\end{array}$ \\
\hline Test: $\mathrm{MV}-\mathrm{MN}=0$ & $\begin{array}{l}-0.066 * * * \\
{[19.15]}\end{array}$ & $\begin{array}{l}-0.060 * * * \\
{[20.39]}\end{array}$ & $\begin{array}{l}-0.040 * * \\
{[5.81]}\end{array}$ \\
\hline \multicolumn{4}{|c|}{ Superv. same sex sample } \\
\hline $\begin{array}{l}\text { Male novoice } \\
(\mathrm{MN})\end{array}$ & $\begin{array}{r}0.007 \\
(0.43) \\
\end{array}$ & $\begin{array}{r}-0.013 \\
(-0.94) \\
\end{array}$ & $\begin{array}{c}-0.009 \\
(-0.50) \\
\end{array}$ \\
\hline $\begin{array}{l}\text { Male voice } \\
\text { (MV) }\end{array}$ & $\begin{array}{l}-0.055 * * * \\
(-2.64)\end{array}$ & $\begin{array}{l}-0.058 * * * \\
(-4.17)\end{array}$ & $\begin{array}{l}-0.039 * * * \\
(-2.79)\end{array}$ \\
\hline Female voice & $\begin{array}{r}-0.021 \\
(-1.58)\end{array}$ & $\begin{array}{l}-0.037 * * * \\
(-3.15)\end{array}$ & $\begin{array}{l}-0.024^{*} \\
(-1.82)\end{array}$ \\
\hline Test: $\mathrm{MV}-\mathrm{MN}=0$ & $\begin{array}{l}-0.062 * * * \\
{[18.14]}\end{array}$ & $\begin{array}{l}-0.045^{* * *} \\
{[12.30]}\end{array}$ & $\begin{array}{l}-0.030^{*} \\
{[3.18]}\end{array}$ \\
\hline \multicolumn{4}{|c|}{ Superv. different sex sample } \\
\hline $\begin{array}{l}\text { Male novoice } \\
(\mathrm{MN})\end{array}$ & $\begin{array}{l}-0.109 * * * \\
(-3.43)\end{array}$ & $\begin{array}{l}-0.068^{* *} \\
(-2.12) \\
\end{array}$ & $\begin{array}{c}-0.050 \\
(-1.23) \\
\end{array}$ \\
\hline $\begin{array}{l}\text { Male voice } \\
(\mathrm{MV})\end{array}$ & $\begin{array}{l}-0.144 * * * \\
(-5.36)\end{array}$ & $\begin{array}{l}-0.155 * * * \\
(-5.65)\end{array}$ & $\begin{array}{l}-0.131 * * * \\
(-4.27)\end{array}$ \\
\hline Female voice & $\begin{array}{l}-0.149 * * * \\
(-5.29)\end{array}$ & $\begin{array}{l}-0.123^{* * *} \\
(-5.06)\end{array}$ & $\begin{array}{l}-0.062 * * \\
(-2.23)\end{array}$ \\
\hline Test: $\mathrm{MV}-\mathrm{MN}=0$ & $\begin{array}{l}-0.035 \\
{[1.17]}\end{array}$ & $\begin{array}{l}-0.087 * * * \\
{[9.21]}\end{array}$ & $\begin{array}{l}-0.081 * * \\
{[5.20]}\end{array}$ \\
\hline
\end{tabular}

Notes: $* * *$, and $* * *$ indicate statistical significance at the $10 \%, 5 \%$ and $1 \%$. Other controls as in Table 5. The comparator group is a female worker with no voice. The 'Test' rows refer to a Wald chi-squared test $(\mathrm{DF}=1)$ for the equality of the coefficients between male workers with voice $(\mathrm{MV})$ and without voice $(\mathrm{MN})$. Numbers in these rows are the difference in marginal probabilities and numbers in brackets are the chi-squared test statistic. The sample average of perceived sex discrimination is $0.085,0.061$ and 0.139 for the full, supervisor same sex and supervisor different sex samples, respectively. 
Table 6. Fully Interacted Model of Voice on Discrimination Claims

\begin{tabular}{|c|c|c|}
\hline \multirow{2}{*}{$\begin{array}{l}\text { Voice measure(s) } \\
\text { Autonomy only }\end{array}$} & Race Discrimination & Sex Discrimination \\
\hline & $\begin{array}{l}-0.016 \\
(-1.45)\end{array}$ & $\begin{array}{c}0.008 \\
(0.37)\end{array}$ \\
\hline Communication only & $\begin{array}{l}-0.0270 * * \\
(-2.41)\end{array}$ & $\begin{array}{c}-0.028 \\
(-1.30)\end{array}$ \\
\hline Seeking info only & $\begin{array}{l}-0.026^{* *} \\
(-2.44)\end{array}$ & $\begin{array}{l}-0.024 \\
(-1.25) \\
\end{array}$ \\
\hline Seeking info + Autonomy & $\begin{array}{l}-0.027 * * * \\
(-2.93)\end{array}$ & $\begin{array}{l}-0.042 * * * \\
(-3.12)\end{array}$ \\
\hline Seeking info + Communication & $\begin{array}{l}-0.046 * * * \\
(-5.45)\end{array}$ & $\begin{array}{l}-0.053 * * * \\
(-3.94) \\
\end{array}$ \\
\hline Communication + Autonomy & $\begin{array}{l}-0.027 * * \\
(-2.22)\end{array}$ & $\begin{array}{l}-0.046^{* * *} \\
(-2.90)\end{array}$ \\
\hline $\begin{array}{l}\text { Seeking info }+ \text { Communication }+ \\
\text { Autonomy }\end{array}$ & $\begin{array}{l}-0.061 * * * \\
(-5.34)\end{array}$ & $\begin{array}{l}-0.096^{* * *} \\
(-6.61)\end{array}$ \\
\hline \multicolumn{3}{|l|}{ Supervisor Different } \\
\hline Autonomy only & $\begin{array}{r}-0.019 \\
(-0.44)\end{array}$ & $\begin{array}{r}0.015 \\
(0.33)\end{array}$ \\
\hline Communication only & $\begin{array}{l}-0.090 * * * \\
(-2.85)\end{array}$ & $\begin{array}{c}-0.039 \\
(-0.76)\end{array}$ \\
\hline Seeking info only & $\begin{array}{l}-0.077 * * \\
(-2.24)\end{array}$ & $\begin{array}{c}-0.046 \\
(-0.99)\end{array}$ \\
\hline Seeking info + Autonomy & $\begin{array}{l}-0.071 * * \\
(-2.18)\end{array}$ & $\begin{array}{l}-0.068 * * \\
(-2.02)\end{array}$ \\
\hline Seeking info + Communication & $\begin{array}{l}-0.128 * * * \\
(-4.66)\end{array}$ & $\begin{array}{l}-0.094 * * * \\
(-2.90)\end{array}$ \\
\hline Communication + Autonomy & $\begin{array}{l}-0.091 * * * \\
(-2.97)\end{array}$ & $\begin{array}{l}-0.088 * * \\
(-2.55)\end{array}$ \\
\hline $\begin{array}{l}\text { Seeking info }+ \text { Communication }+ \\
\text { Autonomy }\end{array}$ & $\begin{array}{l}-0.197 * * * \\
(-5.64)\end{array}$ & $\begin{array}{l}-0.176 * * * \\
(-5.44)\end{array}$ \\
\hline \multicolumn{3}{|l|}{ Supervisor Same } \\
\hline Autonomy only & $\begin{array}{l}-0.013 * \\
(-1.76) \\
\end{array}$ & $\begin{array}{r}0.008 \\
(0.36) \\
\end{array}$ \\
\hline Communication only & $\begin{array}{l}-0.011 \\
(-1.15)\end{array}$ & $\begin{array}{c}-0.023 \\
(-1.08)\end{array}$ \\
\hline Seeking info only & $\begin{array}{l}-0.013 \\
(-1.46)\end{array}$ & $\begin{array}{c}-0.009 \\
(-0.48) \\
\end{array}$ \\
\hline Seeking info + Autonomy & $\begin{array}{l}-0.017 * * \\
(-2.46)\end{array}$ & $\begin{array}{l}-0.032 * * \\
(-2.36)\end{array}$ \\
\hline Seeking info + Communication & $\begin{array}{l}-0.023 * * * \\
(-3.37)\end{array}$ & $\begin{array}{l}-0.035 * * * \\
(-2.63)\end{array}$ \\
\hline Communication + Autonomy & $\begin{array}{r}-0.010 \\
(-1.02) \\
\end{array}$ & $\begin{array}{l}-0.029 \\
(-1.62)\end{array}$ \\
\hline $\begin{array}{l}\text { Seeking info }+ \text { Communication }+ \\
\text { Autonomy }\end{array}$ & $\begin{array}{l}-0.028 * * * \\
(-3.34)\end{array}$ & $\begin{array}{l}-0.062 * * * \\
(-4.25)\end{array}$ \\
\hline
\end{tabular}

Notes: *,**, and *** indicate statistical significance at the $10 \%, 5 \%$ and $1 \%$. Other controls as in Tables 2 and 4 . The comparator group is a worker with no voice. 
Table 7. Selected Results from Interactions of Race and Measures of Voice including Life Satisfaction in Claims of Race Discrimination Regressions: Marginal Effects

\begin{tabular}{|c|c|c|c|}
\hline & \multicolumn{3}{|c|}{ Voice Measure } \\
\hline Covariate & $\begin{array}{c}\text { Seeking } \\
\text { Information }\end{array}$ & $\begin{array}{c}\text { Communication } \\
\text { and Support }\end{array}$ & Autonomy \\
\hline \multicolumn{4}{|l|}{ Full Sample } \\
\hline $\begin{array}{l}\text { White novoice } \\
\text { (WN) }\end{array}$ & $\begin{array}{l}-0.032 * * * \\
(-2.70)\end{array}$ & $\begin{array}{l}-0.038^{* * *} \\
(-3.48)\end{array}$ & $\begin{array}{l}-0.018 \\
(-1.36) \\
\end{array}$ \\
\hline $\begin{array}{l}\text { White voice } \\
\text { (WV) }\end{array}$ & $\begin{array}{l}-0.093 * * * \\
(-5.80)\end{array}$ & $\begin{array}{l}-0.085^{* * * *} \\
(-6.08)\end{array}$ & $\begin{array}{l}-0.046^{* * * *} \\
(-3.21)\end{array}$ \\
\hline Nonwhite voice & $\begin{array}{l}-0.034 * * * \\
(-3.31)\end{array}$ & $\begin{array}{l}-0.039 * * * \\
(-3.93)\end{array}$ & $\begin{array}{r}0.001 \\
(0.08)\end{array}$ \\
\hline Life Satisfaction & $\begin{array}{l}-0.018^{* *} \\
(-2.26)\end{array}$ & $\begin{array}{l}-0.016^{* * *} \\
(-1.98)\end{array}$ & $\begin{array}{l}-0.024 * * * \\
(-2.86)\end{array}$ \\
\hline Test: $\mathrm{WV}-\mathrm{WN}=0$ & $\begin{array}{l}-0.061 * * * \\
{[14.32]}\end{array}$ & $\begin{array}{l}-0.064 * * * \\
{[10.32]}\end{array}$ & $\begin{array}{l}-0.028 * * \\
{[5.23]}\end{array}$ \\
\hline \multicolumn{4}{|c|}{ Superv. same race sample } \\
\hline $\begin{array}{l}\text { White novoice } \\
\text { (WN) }\end{array}$ & $\begin{array}{l}-0.025 * * * \\
(-2.64)\end{array}$ & $\begin{array}{l}-0.028 * * * \\
(-2.72)\end{array}$ & $\begin{array}{l}-0.011 \\
(-0.98)\end{array}$ \\
\hline $\begin{array}{l}\text { White voice } \\
\text { (WV) }\end{array}$ & $\begin{array}{l}-0.088 * * * \\
(-4.31)\end{array}$ & $\begin{array}{l}-0.059 * * * \\
(-3.82)\end{array}$ & $\begin{array}{l}-0.031 * * \\
(-2.16)\end{array}$ \\
\hline Nonwhite voice & $\begin{array}{l}-0.016^{*} \\
(-1.74)\end{array}$ & $\begin{array}{r}-0.013 \\
(-1.16) \\
\end{array}$ & $\begin{array}{c}0.021 \\
(1.07) \\
\end{array}$ \\
\hline Life Satisfaction & $\begin{array}{l}-0.006 \\
(-1.04) \\
\end{array}$ & $\begin{array}{r}-0.006 \\
(-1.00) \\
\end{array}$ & $\begin{array}{l}-0.009 \\
(-1.42) \\
\end{array}$ \\
\hline Test: $\mathrm{WV}-\mathrm{WN}=0$ & $\begin{array}{l}-0.063 * * \\
{[7.73]}\end{array}$ & $\begin{array}{l}-0.031^{*} \\
{[3.20]}\end{array}$ & $\begin{array}{l}-0.020^{*} \\
{[3.57]}\end{array}$ \\
\hline \multicolumn{4}{|c|}{ Superv. different race sample } \\
\hline $\begin{array}{l}\text { White novoice } \\
\text { (WN) }\end{array}$ & $\begin{array}{r}-0.037 \\
(-0.93) \\
\end{array}$ & $\begin{array}{r}-0.043 \\
(-1.40) \\
\end{array}$ & $\begin{array}{l}-0.047 \\
(-1.22) \\
\end{array}$ \\
\hline $\begin{array}{l}\text { White voice } \\
\text { (WV) }\end{array}$ & $\begin{array}{l}-0.138 * * * \\
(-4.54)\end{array}$ & $\begin{array}{l}-0.140 * * * \\
(-5.10)\end{array}$ & $\begin{array}{l}-0.093 * * \\
(-2.54)\end{array}$ \\
\hline Nonwhite voice & $\begin{array}{l}-0.116^{* * * *} \\
(-3.23)\end{array}$ & $\begin{array}{l}-0.148 * * * \\
(-4.73)\end{array}$ & $\begin{array}{c}-0.044 \\
(-1.25) \\
\end{array}$ \\
\hline Life Satisfaction & $\begin{array}{l}-0.050^{*} \\
(-1.74)\end{array}$ & $\begin{array}{r}-0.039 \\
(-1.47)\end{array}$ & $\begin{array}{l}-0.066^{* *} \\
(-2.30)\end{array}$ \\
\hline Test: $\mathrm{WV}-\mathrm{WN}=0$ & $\begin{array}{l}-0.101 * * * \\
{[9.19]}\end{array}$ & $\begin{array}{l}-0.097 * * * \\
{[14.39]}\end{array}$ & $\begin{array}{l}-0.046 \\
{[1.68]}\end{array}$ \\
\hline
\end{tabular}

Notes: Same as Table 3. 
Table 8. Selected Results from Interactions of Sex and Measures of Voice including Life Satisfaction in Claims of Sex Discrimination Regressions: Marginal Effects

\begin{tabular}{|c|c|c|c|}
\hline & \multicolumn{3}{|c|}{ Voice Measure } \\
\hline Covariate & $\begin{array}{c}\text { Seeking } \\
\text { Information }\end{array}$ & $\begin{array}{c}\text { Communication } \\
\text { and Support }\end{array}$ & Autonomy \\
\hline \multicolumn{4}{|l|}{ Full Sample } \\
\hline $\begin{array}{l}\text { Male novoice } \\
(\mathrm{MN})\end{array}$ & $\begin{array}{l}-0.033 * * \\
(-2.34) \\
\end{array}$ & $\begin{array}{l}-0.035^{* * *} \\
(-2.73)\end{array}$ & $\begin{array}{l}-0.031 * \\
(-1.94)\end{array}$ \\
\hline $\begin{array}{l}\text { Male voice } \\
(\mathrm{MV})\end{array}$ & $\begin{array}{l}-0.094 * * * \\
(-6.75)\end{array}$ & $\begin{array}{l}-0.089 * * * \\
(-6.85)\end{array}$ & $\begin{array}{l}-0.067 * * * \\
(-4.88)\end{array}$ \\
\hline Female voice & $\begin{array}{l}-0.053 * * * \\
(-4.42)\end{array}$ & $\begin{array}{l}-0.056 * * * \\
(-5.16)\end{array}$ & $\begin{array}{l}-0.032 * * \\
(-2.58)\end{array}$ \\
\hline Life Satisfaction & $\begin{array}{l}-0.033 * * * \\
(-3.32)\end{array}$ & $\begin{array}{l}-0.030 * * * \\
(-3.02)\end{array}$ & $\begin{array}{l}-0.041 * * * \\
(-4.00)\end{array}$ \\
\hline Test: $\mathrm{MV}-\mathrm{MN}=0$ & $\begin{array}{l}-0.061 * * * \\
{[16.05]}\end{array}$ & $\begin{array}{l}-0.054 * * * \\
{[16.62]}\end{array}$ & $\begin{array}{l}-0.036^{* *} \\
{[4.65]}\end{array}$ \\
\hline \multicolumn{4}{|c|}{ Superv. same sex sample } \\
\hline $\begin{array}{l}\text { Male novoice } \\
(\mathrm{MN})\end{array}$ & $\begin{array}{c}0.008 \\
(0.45)\end{array}$ & $\begin{array}{c}-0.013 \\
(-0.97)\end{array}$ & $\begin{array}{c}-0.010 \\
(-0.60)\end{array}$ \\
\hline $\begin{array}{l}\text { Male voice } \\
(\mathrm{MV})\end{array}$ & $\begin{array}{l}-0.051 * * * \\
(-3.36)\end{array}$ & $\begin{array}{l}-0.053 * * * \\
(-3.85)\end{array}$ & $\begin{array}{l}-0.036 * * * \\
(-2.64)\end{array}$ \\
\hline Female voice & $\begin{array}{c}-0.018 \\
(-1.36) \\
\end{array}$ & $\begin{array}{l}-0.035 * * * \\
(-2.89)\end{array}$ & $\begin{array}{l}-0.023^{*} \\
(-1.78) \\
\end{array}$ \\
\hline Life Satisfaction & $\begin{array}{l}-0.021 * * \\
(-2.14)\end{array}$ & $\begin{array}{l}-0.017 * \\
(-1.73) \\
\end{array}$ & $\begin{array}{l}-0.026 * * * \\
(-2.61)\end{array}$ \\
\hline Test: $\mathrm{MV}-\mathrm{MN}=0$ & $\begin{array}{l}-0.059 * * * \\
{[15.72]}\end{array}$ & $\begin{array}{l}-0.040 * * * \\
{[10.05]}\end{array}$ & $\begin{array}{l}-0.026 \\
{[2.48]}\end{array}$ \\
\hline \multicolumn{4}{|c|}{ Superv. different sex sample } \\
\hline $\begin{array}{l}\text { Male novoice } \\
(\mathrm{MN})\end{array}$ & $\begin{array}{l}-0.108 * * * \\
(-3.51)\end{array}$ & $\begin{array}{l}-0.069 * * \\
(-2.20) \\
\end{array}$ & $\begin{array}{l}-0.052 \\
(-1.30) \\
\end{array}$ \\
\hline $\begin{array}{l}\text { Male voice } \\
(\mathrm{MV})\end{array}$ & $\begin{array}{l}-0.137 * * * \\
(-5.10)\end{array}$ & $\begin{array}{l}-0.151 * * * \\
(-5.57)\end{array}$ & $\begin{array}{l}-0.126 * * * \\
(-4.19)\end{array}$ \\
\hline Female voice & $\begin{array}{l}-0.136 * * * \\
(-4.89)\end{array}$ & $\begin{array}{l}-0.114 * * * \\
(-4.74)\end{array}$ & $\begin{array}{l}-0.052^{*} \\
(-1.90)\end{array}$ \\
\hline Life Satisfaction & $\begin{array}{l}-0.062 * * * \\
(-2.68)\end{array}$ & $\begin{array}{l}-0.062 * * * \\
(-2.69)\end{array}$ & $\begin{array}{l}-0.073 * * * \\
(-3.14)\end{array}$ \\
\hline Test: $\mathrm{MV}-\mathrm{MN}=0$ & $\begin{array}{l}-0.029 \\
{[0.66]}\end{array}$ & $\begin{array}{l}-0.082 * * * \\
{[8.23]}\end{array}$ & $\begin{array}{l}-0.074 * * \\
{[4.46]}\end{array}$ \\
\hline
\end{tabular}

Notes: Same as in Table 5. 
Table 9. Selected Results from Interactions of Race and Measures of Voice including Predicted Wage Differential in Claims of Race Discrimination Regressions: Marginal Effects

\begin{tabular}{|c|c|c|c|}
\hline & \multicolumn{3}{|c|}{ Voice Measure } \\
\hline Covariate & $\begin{array}{c}\text { Seeking } \\
\text { Information }\end{array}$ & $\begin{array}{l}\text { Communication } \\
\text { and Support }\end{array}$ & Autonomy \\
\hline \multicolumn{4}{|l|}{ Full Sample } \\
\hline $\begin{array}{l}\text { White novoice } \\
\text { (WN) }\end{array}$ & $\begin{array}{l}-0.032 * * * \\
(-2.70)\end{array}$ & $\begin{array}{l}-0.039 * * * \\
(-3.52)\end{array}$ & $\begin{array}{c}-0.019 \\
(-1.40)\end{array}$ \\
\hline $\begin{array}{l}\text { White voice } \\
\text { (WV) }\end{array}$ & $\begin{array}{l}-0.099 * * * \\
(-6.04)\end{array}$ & $\begin{array}{l}-0.091 * * * \\
(-6.33)\end{array}$ & $\begin{array}{l}-0.051 \text { *** } \\
(-3.41)\end{array}$ \\
\hline Nonwhite voice & $\begin{array}{l}-0.035 * * * \\
(-3.37)\end{array}$ & $\begin{array}{l}-0.041 * * * \\
(-4.02)\end{array}$ & $\begin{array}{c}-0.001 \\
(-0.03)\end{array}$ \\
\hline Wage Differential & $\begin{array}{r}0.001 \\
(0.04)\end{array}$ & $\begin{array}{c}-0.003 \\
(-0.17)\end{array}$ & $\begin{array}{l}-0.0004 \\
(-0.02)\end{array}$ \\
\hline Test: $\mathrm{WV}-\mathrm{WN}=0$ & $\begin{array}{l}-0.067 * * * \\
{[17.49]}\end{array}$ & $\begin{array}{l}-0.052 * * * \\
{[12.43]}\end{array}$ & $\begin{array}{l}-0.035 * * \\
{[6.22]}\end{array}$ \\
\hline \multicolumn{4}{|c|}{ Superv. same race sample } \\
\hline $\begin{array}{l}\text { White novoice } \\
\text { (WN) }\end{array}$ & $\begin{array}{l}-0.026 * * * \\
(-2.75)\end{array}$ & $\begin{array}{l}-0.031 * * * \\
(-3.23)\end{array}$ & $\begin{array}{c}-0.013 \\
(-1.24)\end{array}$ \\
\hline $\begin{array}{l}\text { White voice } \\
\text { (WV) }\end{array}$ & $\begin{array}{l}-0.095 * * * \\
(-4.46)\end{array}$ & $\begin{array}{l}-0.070 * * * \\
(-4.33)\end{array}$ & $\begin{array}{l}-0.037 * * \\
(-2.42)\end{array}$ \\
\hline Nonwhite voice & $\begin{array}{l}-0.016^{*} \\
(-1.69) \\
\end{array}$ & $\begin{array}{c}-0.014 \\
(-1.37) \\
\end{array}$ & $\begin{array}{r}0.023 \\
(1.12) \\
\end{array}$ \\
\hline Wage Differential & $\begin{array}{c}-0.008 \\
(-0.58)\end{array}$ & $\begin{array}{l}-0.013 \\
(-0.93)\end{array}$ & $\begin{array}{c}-0.016 \\
(-1.05)\end{array}$ \\
\hline Test: WV-WN=0 & $\begin{array}{l}-0.069 * * * \\
{[8.97]}\end{array}$ & $\begin{array}{l}-0.039 * \\
{[3.68]}\end{array}$ & $\begin{array}{l}-0.024 * * \\
{[4.14]}\end{array}$ \\
\hline \multicolumn{4}{|c|}{ Superv. different race sample } \\
\hline $\begin{array}{l}\text { White novoice } \\
\text { (WN) }\end{array}$ & $\begin{array}{l}-0.043 \\
(-1.05)\end{array}$ & $\begin{array}{l}-0.050 \\
(-1.55)\end{array}$ & $\begin{array}{c}-0.059 \\
(-1.49)\end{array}$ \\
\hline $\begin{array}{l}\text { White voice } \\
\text { (WV) }\end{array}$ & $\begin{array}{l}-0.154 * * * \\
(-4.80)\end{array}$ & $\begin{array}{l}-0.150 * * * \\
(-5.36)\end{array}$ & $\begin{array}{l}-0.109 \text { *** } \\
(-2.87)\end{array}$ \\
\hline Nonwhite voice & $\begin{array}{l}-0.116^{* * * *} \\
(-3.26)\end{array}$ & $\begin{array}{l}-0.151 * * * \\
(-4.82)\end{array}$ & $\begin{array}{c}-0.049 \\
(-1.39)\end{array}$ \\
\hline Wage Differential & $\begin{array}{r}0.070 \\
(1.22)\end{array}$ & $\begin{array}{c}0.046 \\
(0.83)\end{array}$ & $\begin{array}{c}0.058 \\
(0.99)\end{array}$ \\
\hline Test: WV-WN=0 & $\begin{array}{l}-0.111 * * * \\
{[12.41]}\end{array}$ & $\begin{array}{l}-0.010 * * * \\
{[16.35]}\end{array}$ & $\begin{array}{l}-0.050 \\
{[2.17]}\end{array}$ \\
\hline
\end{tabular}

Notes: Same as Table 3. 
Table 10. Selected Results from Interactions of Sex and Measures of Voice including Predicted Wage Differential in Claims of Sex Discrimination Regressions: Marginal Effects

\begin{tabular}{|c|c|c|c|}
\hline & \multicolumn{3}{|c|}{ Voice Measure } \\
\hline Covariate & $\begin{array}{c}\text { Seeking } \\
\text { Information }\end{array}$ & $\begin{array}{l}\text { Communication } \\
\text { and Support }\end{array}$ & Autonomy \\
\hline \multicolumn{4}{|l|}{ Full Sample } \\
\hline $\begin{array}{l}\text { Male novoice } \\
\text { (MN) }\end{array}$ & $\begin{array}{l}-0.042^{* *} \\
(-2.33)\end{array}$ & $\begin{array}{l}-0.043 * * \\
(-2.37)\end{array}$ & $\begin{array}{l}-0.040^{* *} \\
(-2.13)\end{array}$ \\
\hline $\begin{array}{l}\text { Male voice } \\
\text { (MV) }\end{array}$ & $\begin{array}{l}-0.109 * * * \\
(-6.25)\end{array}$ & $\begin{array}{l}-0.102 * * * \\
(-6.44)\end{array}$ & $\begin{array}{l}-0.083^{* * *} \\
(-4.27)\end{array}$ \\
\hline Female voice & $\begin{array}{l}-0.058 * * * \\
(-4.86)\end{array}$ & $\begin{array}{l}-0.060 * * * \\
(-5.58)\end{array}$ & $\begin{array}{l}-0.035^{* * *} \\
(-2.81)\end{array}$ \\
\hline Wage Differential & $\begin{array}{c}-0.020 \\
(-0.88)\end{array}$ & $\begin{array}{c}-0.018 \\
(-0.80)\end{array}$ & $\begin{array}{l}-0.025 \\
(-1.10)\end{array}$ \\
\hline Test: $\mathrm{MV}-\mathrm{MN}=0$ & $\begin{array}{l}-0.067 * * * \\
{[19.31]}\end{array}$ & $\begin{array}{l}-0.059 * * * \\
{[20.23]}\end{array}$ & $\begin{array}{l}-0.043 * * \\
{[6.22]}\end{array}$ \\
\hline \multicolumn{4}{|c|}{ Superv. same sex sample } \\
\hline $\begin{array}{l}\text { Male novoice } \\
(\mathrm{MN})\end{array}$ & $\begin{array}{l}-0.0004 \\
(-0.02)\end{array}$ & $\begin{array}{c}-0.019 \\
(-0.85)\end{array}$ & $\begin{array}{l}-0.016 \\
(-0.69)\end{array}$ \\
\hline $\begin{array}{l}\text { Male voice } \\
(\mathrm{MV})\end{array}$ & $\begin{array}{l}-0.063 * * * \\
(-2.89)\end{array}$ & $\begin{array}{l}-0.064 * * * \\
(-3.15)\end{array}$ & $\begin{array}{l}-0.047 * \\
(-1.94)\end{array}$ \\
\hline Female voice & $\begin{array}{r}-0.021 \\
(-1.56) \\
\end{array}$ & $\begin{array}{l}-0.037 * * * \\
(-3.15)\end{array}$ & $\begin{array}{l}-0.024 * \\
(-1.78)\end{array}$ \\
\hline Wage Differential & $\begin{array}{l}-0.010 \\
(-0.42)\end{array}$ & $\begin{array}{c}-0.001 \\
(-0.40)\end{array}$ & $\begin{array}{l}-0.012 \\
(-0.45)\end{array}$ \\
\hline Test: $\mathrm{MV}-\mathrm{MN}=0$ & $\begin{array}{l}-0.063 * * * \\
{[18.41]}\end{array}$ & $\begin{array}{l}-0.045^{* * * *} \\
{[12.62]}\end{array}$ & $\begin{array}{l}-0.031 * \\
{[3.23]}\end{array}$ \\
\hline \multicolumn{4}{|c|}{ Superv. different sex sample } \\
\hline $\begin{array}{l}\text { Male novoice } \\
(\mathrm{MN})\end{array}$ & $\begin{array}{l}-0.115 * * * \\
(-3.40)\end{array}$ & $\begin{array}{l}-0.075^{* *} \\
(-2.12)\end{array}$ & $\begin{array}{l}-0.059 \\
(-1.46)\end{array}$ \\
\hline $\begin{array}{l}\text { Male voice } \\
\text { (MV) }\end{array}$ & $\begin{array}{l}-0.149 * * * \\
(-5.21)\end{array}$ & $\begin{array}{l}-0.158 * * * \\
(-5.38)\end{array}$ & $\begin{array}{l}-0.139 * * * \\
(-4.07)\end{array}$ \\
\hline Female voice & $\begin{array}{l}-0.148 * * * \\
(-5.28)\end{array}$ & $\begin{array}{l}-0.123 * * * \\
(-5.06)\end{array}$ & $\begin{array}{l}-0.060^{* *} \\
(-2.17)\end{array}$ \\
\hline Wage Differential & $\begin{array}{c}-0.043 \\
(-0.71)\end{array}$ & $\begin{array}{c}-0.030 \\
(-0.51)\end{array}$ & $\begin{array}{l}-0.052 \\
(-0.88)\end{array}$ \\
\hline Test: $\mathrm{MV}-\mathrm{MN}=0$ & $\begin{array}{l}-0.034 \\
{[1.00]}\end{array}$ & $\begin{array}{l}-0.083 * * * \\
{[8.97]}\end{array}$ & $\begin{array}{l}-0.080 * * \\
{[5.32]}\end{array}$ \\
\hline
\end{tabular}

Notes: Same as in Table 5. 
Appendix Table 1: Descriptive Statistics

\begin{tabular}{|c|c|c|c|c|c|}
\hline Variable & Full & Female & Male & White & Nonwhite \\
\hline Race Discrimination & $6.0 \%$ & $3.8 \%$ & $8.1 \%$ & $3.6 \%$ & $13.8 \%$ \\
\hline Sex Discrimination & 8.5 & 11.6 & 5.4 & 8.4 & 8.6 \\
\hline Nonwhite & 23.4 & 22.3 & 24.4 & 0 & 100 \\
\hline Female & 48.9 & 100 & 0 & 49.6 & 46.6 \\
\hline Union member & 17.8 & 15.5 & 20.0 & 17.3 & 19.6 \\
\hline$<$ High School diploma & 10.2 & 7.3 & 12.8 & 7.1 & 20.1 \\
\hline High School diploma & 30.4 & 29.5 & 31.3 & 30.6 & 30.0 \\
\hline Some college, no degree & 20.8 & 21.5 & 20.2 & 20.4 & 22.1 \\
\hline Associates degree & 9.4 & 9.8 & 9.0 & 10.1 & 7.2 \\
\hline University degree & 20.0 & 22.8 & 17.3 & 21.7 & 14.2 \\
\hline Postgraduate degree & 9.2 & 9.1 & 9.4 & 10.1 & 6.4 \\
\hline Age & $\begin{array}{c}41.1 \\
(12.7) \\
\end{array}$ & $\begin{array}{c}42.2 \\
(12.8) \\
\end{array}$ & $\begin{array}{c}40.0 \\
(12.5) \\
\end{array}$ & $\begin{array}{c}42.0 \\
(12.7)\end{array}$ & $\begin{array}{c}38.1 \\
(12.2)\end{array}$ \\
\hline Age squared & $\begin{array}{c}1851.3 \\
(1090.4) \\
\end{array}$ & $\begin{array}{c}1947.7 \\
(1124.8) \\
\end{array}$ & $\begin{array}{c}1759.0 \\
(1048.6) \\
\end{array}$ & $\begin{array}{c}1928.3 \\
(1109.5) \\
\end{array}$ & $\begin{array}{l}1599.1 \\
(985.2)\end{array}$ \\
\hline Managerial occ & 14.2 & 15.5 & 13.0 & 14.8 & 12.3 \\
\hline Professional occ & 19.8 & 24.0 & 15.8 & 21.8 & 13.2 \\
\hline Technical occ & 4.1 & 4.6 & 3.6 & 4.4 & 3.2 \\
\hline Sales occ & 9.1 & 10.8 & 7.4 & 9.4 & 8.0 \\
\hline Admin Support occ & 14.0 & 21.2 & 7.2 & 13.8 & 14.9 \\
\hline Service occ & 12.4 & 13.6 & 11.2 & 11.4 & 15.5 \\
\hline Production/operation occ & 26.4 & 10.3 & 41.8 & 24.4 & 32.9 \\
\hline Tenure $<12$ years & 25.7 & 26.7 & 24.8 & 22.0 & 38.1 \\
\hline Tenure b/t 12-21 years & 25.3 & 24.6 & 25.9 & 24.9 & 26.6 \\
\hline Tenure b/t 22-30 years & 26.3 & 29.1 & 23.7 & 28.4 & 19.4 \\
\hline Tenure $>30$ years & 22.7 & 19.6 & 25.6 & 24.7 & 15.9 \\
\hline
\end{tabular}

Notes: Data are weighted averages from the 2002 NSCW. Numbers in parentheses are standard deviations of continuous variables. 